University of Nebraska - Lincoln

DigitalCommons@University of Nebraska - Lincoln

Agronomy \& Horticulture -- Faculty Publications

Agronomy and Horticulture Department

2011

\title{
Registration of 'Anton' Hard White Winter Wheat
}

\author{
Robert A. Graybosch \\ University of Nebraska-Lincoln, bob.graybosch@ars.usda.gov \\ C. James Peterson \\ Limagrain Cereal Seeds \\ P. Stephen Baenziger \\ University of Nebraska-Lincoln, pbaenziger1@unl.edu \\ David D. Baltensperger \\ Texas A\&M University, dbaltensperger@tamu.edu \\ Lenis Alton Nelson \\ University of Nebraska-Lincoln, Inelson1@unl.edu
}

See next page for additional authors

Follow this and additional works at: https://digitalcommons.unl.edu/agronomyfacpub

Part of the Plant Sciences Commons

Graybosch, Robert A.; Peterson, C. James; Baenziger, P. Stephen; Baltensperger, David D.; Nelson, Lenis Alton; Jin, Yue; Kolmer, James A.; Seabourn, Bradford W.; and Beecher, Brian S., "Registration of 'Anton' Hard White Winter Wheat" (2011). Agronomy \& Horticulture -- Faculty Publications. 604.

https://digitalcommons.unl.edu/agronomyfacpub/604

This Article is brought to you for free and open access by the Agronomy and Horticulture Department at DigitalCommons@University of Nebraska - Lincoln. It has been accepted for inclusion in Agronomy \& Horticulture -Faculty Publications by an authorized administrator of DigitalCommons@University of Nebraska - Lincoln. 


\section{Authors}

Robert A. Graybosch, C. James Peterson, P. Stephen Baenziger, David D. Baltensperger, Lenis Alton Nelson, Yue Jin, James A. Kolmer, Bradford W. Seabourn, and Brian S. Beecher 


\title{
Registration of 'Anton' Hard White Winter Wheat
}

\author{
Robert A. Graybosch, ${ }^{\star}$ C. James Peterson, P. Stephen Baenziger, David D. Baltensperger, \\ Lenis A. Nelson, Yue Jin, James A. Kolmer, Bradford W. Seabourn, and Brian S. Beecher
}

\begin{abstract}
Low levels of the grain enzyme polyphenol oxidase (PPO) are a necessary attribute of any newly developed hard white wheat (Triticum aestivum L.) adapted to the Great Plains. Low PPO correlates with enhanced end-use quality, including the final product color in noodle applications. Few wheats with this necessary characteristic presently are available. The objective of this study was to develop a hard winter wheat adapted to the region that possesses both low levels of grain PPO and quality characteristics that would allow its utilization in domestic bread-making applications. This goal was achieved via the development and release in December 2007 of 'Anton' (Reg. No. CV-1057, PI 651044) hard white winter wheat by the USDA-ARS and the Nebraska Agricultural Experiment Station. Anton was released primarily for its low levels of PPO. Flour-PPO levels of Anton (tested under the experimental designation NW98S097) were significantly lower than all other entries in the 2003 and 2004 USDA-ARS coordinated Northern Regional Performance nursery. Polyphenol oxidase levels of Anton in grain from the 2005 University of Nebraska cultivar performance trials were not significantly different from those of the low-PPO cultivar 'Platte' and were significantly lower than those of several additional current hard white winter wheat cultivars and breeding lines. Anton was selected from the cross WA691213-27/N86L177//Platte.
\end{abstract}

0 ver the past two decades, wheat breeders have attempted to diversify the wheat production system of the Great Plains via the introduction of hard white wheats (Triticum aestivum L.). While great progress in grain yield potential and disease resistance has been made, much of the current hard white wheat germplasm lacks two essential quality traits, namely, resistance to preharvest sprouting and low levels of the grain enzyme polyphenol oxidase (PPO). Low PPO correlates with low amounts of discoloration of fresh dough and noodle products and may also correlate with improved bread-making quality. Low levels

R.A. Graybosch, USDA-ARS, 137 Keim Hall, Univ. of Nebraska, Lincoln, NE 68583; C.J. Peterson, Limagrain Cereal Seeds, 3515 E. Richards Lake Rd., Ft. Collins, CO 80524; P.S. Baenziger and L.A. Nelson, Dep. of Agronomy and Horticulture, Univ. of Nebraska, Lincoln, NE 68583; D.D. Baltensperger, Dep. of Soil and Crop Sciences, Texas A\&M Univ., College Station, TX 77843; Y. Jin and J.A. Kolmer, USDAARS, Cereal Disease Lab., Univ. of Minnesota, St. Paul, MN 55108; B.W. Seabourn, USDA-ARS, Hard Winter Wheat Quality Lab., Manhattan, KS 66502; and B.S. Beecher, USDA-ARS, Washington State Univ., Pullman, WA 99164. Registration by CSSA. Received 20 Aug. 2010. ${ }^{\star}$ Corresponding author (bob.graybosch@ars.usda.gov).

Abbreviations: NRPN, Northern Regional Performance Nursery; PPO, polyphenol oxidase.

Published in the Journal of Plant Registrations 5:339-344 (2011). doi: 10.3198/jpr2010.08.0481crc

Posted online 26 Apr. 2011

(C) Crop Science Society of America

5585 Guilford Rd., Madison, WI 53711 USA

All rights reserved. No part of this periodical may be reproduced or transmitted in any form or by any means, electronic or mechanical, including photocopying, recording, or any information storage and retrieval system, without permission in writing from the publisher. Permission for printing and for reprinting the material contained herein has been obtained by the publisher. of grain PPO are necessary to meet both domestic and import demand for hard white wheats. To date, few lowPPO winter wheats other than 'Platte' (PVP 9700012) and 'Lakin' (PI 617032) have been released for production in the Great Plains region. To meet the demand for low-PPO hard white winter wheats, the USDA-ARS and Nebraska Agricultural Experiment Station cooperatively developed and released the hard white winter wheat cultivar 'Anton' (Reg. No. CV-1057, PI 651044). Anton was released primarily for its low levels of grain and flour PPO. The name Anton was chosen to honor the memory of Anton Joseph Graybosch, Sr., and Anton Joseph Graybosch, Jr., grandfather and father of the corresponding author.

\section{Methods}

\section{Early-Generation Population Development}

Anton was developed using a modified bulk-breeding procedure, followed by reselection for uniformity of seedcoat color. Anton was selected from the cross WA69121327/N86L177//Platte. WA691213-27 is a soft white winter wheat breeding line developed by Washington State University. WA691213-27 was derived from the cross 'Brevor' (CItr 12385)/CItr 15923//'Nugaines' (CItr 13968) and is a sister line of the cultivar 'Dusty' (PI 486429; Peterson et al., 1987). N86L177 (PI 559717; Peterson et al., 1993) is a high-protein strong-gluten hard red winter wheat developed by USDA-ARS and derived from the cross Nap Hal (PI 176223) 'Lancer' (CItr 13547)//'Karlik 1'/3/NS 622 (PI 323639)/4/“Centurk' (CItr 15075)/‘GK-Tiszataj'// 'Plainsman V' (PI 591702). Platte is a low grain-PPO hard white winter wheat developed by HybriTech Seed International, a former unit of Monsanto Company. 


\section{Line Selection and Evaluation}

The final cross in the development of Anton was made in 1993. The $F_{1}$ generation was grown in the field at Yuma, AZ in 1994, and the $\mathrm{F}_{2}-\mathrm{F}_{3}$ generations were advanced using the bulk-breeding method in the field at Lincoln, NE in 1995 and 1996. In 1997, Anton was selected as a single $\mathrm{F}_{3}: \mathrm{F}_{4}$ headrow grown at Lincoln, NE. In 1998, Anton was entered in an unreplicated $\mathrm{F}_{5}$ preliminary observation trial at Sidney, $\mathrm{NE}$, with subsequent $\mathrm{F}_{6}$ and $\mathrm{F}_{7}$ generations tested in multilocation yield trials in Nebraska in 1999 and 2000. At this time, Anton was detected as being heterogeneous for red and white grain color. In 2000, 10 uniformly white-grained heads were selected from field plantings at Lincoln, NE and grown in single 3-m rows in the field at Yuma, AZ. Seed harvested from these 10 rows was combined and increased. Anton, tested under the experimental line designation NW985097, was then submitted for testing in regional and statewide trials. Anton was evaluated in the USDA-ARS Northern Regional Performance Nursery (NRPN) in 2003 (15 environments) and 2004 (14 environments) and in the University of Nebraska cultivar performance trials in 2005-2007 (37 rainfed environments; 11 irrigated). Results from the University of Nebraska trial are given by reporting districts (UNL, 2010) with separate analyses conducted for each.

\section{Seed Purification and Increase}

Large-scale seed purification began in 2004. Seed harvested from the advanced yield trials at Lincoln, NE in 2004 was planted in an unreplicated strip plot at Yuma, AZ. In the fall of 2005, seed from Yuma, AZ was used to plant a breederseed increase near Hemingford, NE. In 2006, a foundationseed increase was planted by the Nebraska Foundation Seed Division. Anton has been stable and uniform since 2000.

\section{End-Use Quality Analyses}

End-use quality evaluations of Anton were conducted by the USDA-ARS Hard Winter Wheat Quality Laboratory, Manhattan, KS, on samples obtained from the 2003 and 2004 NRPN, composited by agro-ecological production zone (Peterson, 1992). Six samples (three production-zone composites per year) were evaluated from this 2 -yr period. Measured traits reported herein include kernel weight (mg), grain hardness score (hardness units), grain protein concentration $\left(\mathrm{g} \mathrm{kg}^{-1}\right)$, flour milling yield $\left(\mathrm{g} \mathrm{kg}^{-1}\right)$, flour ash content $\left(\mathrm{g} \mathrm{kg}^{-1}\right)$, flour-PPO levels, flour-protein concentration $\left(\mathrm{g} \mathrm{kg}^{-1}\right)$, Mixograph (National Mfg., Lincoln, NE) water absorption $\left(\mathrm{g} \mathrm{kg}^{-1}\right)$, Mixograph time (min), Mixograph tolerance $(0-6,0=$ weak, and $6=$ strong), bake water absorption $\left(\mathrm{g} \mathrm{kg}^{-1}\right)$, bake mix time (min), loaf crumb score (0-5), and loaf volume $(\mathrm{ml})$ (procedures described in USDA-ARS, 2009a). Alkaline noodle-color stability was assessed by measuring change in color over $24 \mathrm{~h}$ by a Minolta colorimeter (Minolta Corp., Ramsey, NJ). The direct reflected measurements were L, brightness; a, red/green color; and b, blue/yellow color. Grain-PPO activity (Anderson and Morris, 2001) was evaluated from samples collected from nine locations of the University of Nebraska wheat variety trial in 2005 and compared with that of the cultivars Platte,
'Antelope' (PI 633910), 'Trego' (PI 612576), and 'Nuplains' (PI 605741) and the experimental hard white wheat breeding lines NW97S139-1 (PI 642411), NP-02, and NW99L7068. NP-02 is a reselection of the cultivar Nuplains. The subunit composition of high-molecular-weight glutenin was evaluated via sodium dodecyl sulfate polyacrylamide electrophoresis according to procedures described by Blechl and Anderson (1996) and the allelic designations established by Payne and Lawrence (1983). The phenol reaction of the grain was determined by the Illinois Crop Improvement Association, Champaign, IL.

\section{Tolerance to Preharvest Sprouting}

Tolerance to preharvest sprouting of Anton was assessed from experiments grown at Mead, NE in 2007-2009. Entries were seeded in a randomized block design with six field blocks and unequal numbers of entries per block. Each entry occurred at least once per block. The study included the hard red winter wheat cultivars and breeding lines 'Alliance' (PI 573096), 'Arapahoe' (PI 518591), 'Jagalene' (PVP 200200160), 'Camelot' (PI 653832), NE02584, NI01481, NI04420, 'NE01643' (PI 647959, marketed as Husker Genetics Overland), 'Pronghorn' (PI 593047), and 'Wesley' (PI 605742) and the hard white winter wheat cultivars Antelope, 'Arrowsmith'(PI 633911), Nuplains, Platte, and Trego. At physiological maturity, which was identified by the loss of chlorophyll from the peduncle, 20 heads were snapped per plot. Heads were dried overnight at $90^{\circ} \mathrm{C}$ and then stored at $-20^{\circ} \mathrm{C}$ until assayed. Two replications of 10 heads per plot were tested each harvest year. The total two-dimensional area $\left(\mathrm{cm}^{2}\right)$ of a 10-head sample was determined by measurement with a LI-COR (Lincoln, NE) LI-3100C Area Meter. The heads subsequently were placed for $7 \mathrm{~d}$ in a growth chamber set at a constant temperature of $21^{\circ} \mathrm{C}$ with a diurnal regime of $18 \mathrm{~h}$ light $/ 6 \mathrm{~h}$ dark. Heads were misted six times daily for $20 \mathrm{~min}$ at 4 -h intervals. After $7 \mathrm{~d}$, the total area of the 10-head sample was again measured with the LI-COR Area Meter. The change in area ( $\Delta$ area), which was due to shoot and root growth, was calculated as the difference in total head area before and after misting. Lower $\Delta$ areas were considered indicative of greater tolerance to preharvest sprouting.

\section{Statistical Analyses}

All statistical analyses were accomplished using SAS version 9.1 (SAS Institute, Cary, NC). PROC GLM was used to evaluate grain yield, end-use quality, and grain PPO data. Sample means were compared by computation of least significant differences (LSD = 0.05). PROC GLM also was used for statistical analysis of the preharvest sprouting data, with lines compared via computation of least squared means and standard errors.

\section{Characteristics Agronomic and Botanical Description}

Anton is a semidwarf hard white winter wheat. The spike is oblong, erect, and awned. The glumes are white, with an acuminate beak and an oblique shoulder. The seed shape 
is oval, with a midsized brush of short-to-medium hairs. The embryo is midsized, and the seed crease width is narrow and middeep. In the 2003 and 2004 NRPN, the mature plant height of Anton averaged 79 and $71 \mathrm{~cm}$, respectively, which was not significantly different from the check cultivars Nuplains and 'Nekota' (PI 584997) (Table 1). Average days from 1 January to heading in the 2003 NRPN were as follows: Anton, 162; Nuplains, 163; Nekota, 159. In the 2004 NRPN, Anton headed an average of 4 d later than Nekota and $1 \mathrm{~d}$ earlier than Nuplains (Table 1). Based on data from 37 rainfed Nebraska environments in 2005-2007, the mature plant height of Anton was $79 \mathrm{~cm}, 2 \mathrm{~cm}$ taller than Wesley, $2 \mathrm{~cm}$ shorter than Antelope, and $9 \mathrm{~cm}$ shorter than 'Millennium' (PI 613099). Lodging resistance was excellent (Table 2) under both rainfed and irrigated conditions. In the 2005-2007 crop years, the average heading date of Anton was $149 \mathrm{~d}$ from 1 January, $1 \mathrm{~d}$ later than Millennium and Wesley and $3 \mathrm{~d}$ later than Antelope. The field appearance of Anton is most similar to Platte's. The juvenile plant growth form is erect, anthocyanin is absent from the coleoptile and stem, the anther color is yellow, the foliage is green, and the stem is hollow. The grain-phenol reaction of Anton is light brown.

\section{Disease and Insect Resistance}

Anton is moderately resistant to resistant to the following races of wheat stem rust (caused by Puccinia graminis Pers.: Pers. f. sp. tritici Eriks \& E. Henn.): TTTT, TPMK, QTHJ, QFCS, RCRS, and RTQQ. Anton also is moderately resistant to resistant to leaf rust (caused by $P$. triticina Eriks.) races CBMT, MCDS, MBDS, MHDS, MCRK, and THBJ. Anton is postulated as carrying the stem rust-resistance gene $\mathrm{Sr} 24$ and the leaf rust-resistance gene Lr24, plus at least one additional unidentified leaf rust-resistance gene. It is susceptible to the Great Plains races of stripe rust (caused by P. striiformis Westendorp f. sp. tritici) and is susceptible to the Hessian fly (Mayetiola destructor Say), the Russian wheat aphid [Diuraphis noxia (Mordvilko)], and the greenbug [Schizaphis graminum (Rondani)]. Anton is susceptible to field and artificial inoculations of Wheat streak mosaic virus but resistant to natural infestations by Wheat soilborne mosaic virus (WSBMV). Documentation of disease responses of Anton is available at the website of the USDAARS-coordinated Hard Winter Wheat Regional Nursery Program (USDA-ARS, 2009b).

\section{Field Performance}

In the 2003 USDA-ARS-coordinated NRPN, the grain yield of Anton was not significantly different from that of either the hard red winter wheat check cultivar Nekota or the hard white winter wheat check cultivar Nuplains (Table 1). In 2004, the grain yield of Anton again was statistically equal to that of Nuplains and statistically greater than that of Nekota (Table 1). In the University of Nebraska statewide variety trials conducted over the harvest years 2005-2007 (Table 2), the grain yield of Anton was not significantly different from that of the hard red winter wheat cultivars Millennium, Wesley, and 'Mace' (PI 651043) nor from that of the hard white winter wheat check cultivar Antelope, in
Table 1. Agronomic properties of Anton, relative to check varieties, in the 2003 (15 environments) and 2004 (17 environments) USDA-ARS coordinated Northern Regional Performance Nurseries.

\begin{tabular}{|c|c|c|c|c|}
\hline Cultivar & Yield & $\begin{array}{l}\text { Grain } \\
\text { volume } \\
\text { weight }\end{array}$ & $\begin{array}{l}\text { Mean days } \\
\text { from } 1 \text { Jan. } \\
\text { to heading }\end{array}$ & $\begin{array}{c}\text { Plant } \\
\text { height }\end{array}$ \\
\hline & $\mathrm{kg} \mathrm{ha}^{-1}$ & $\mathrm{~kg} \mathrm{hL}^{-1}$ & $d$ & $\mathrm{~cm}$ \\
\hline & \multicolumn{4}{|c|}{2003} \\
\hline Nuplains & 4059 & 76.9 & 163 & 80 \\
\hline Nekota & 4066 & 75.2 & 159 & 81 \\
\hline Anton & 3795 & 73.9 & 162 & 79 \\
\hline Average all entries ${ }^{\dagger}$ & 4158 & 74.5 & 161 & 84 \\
\hline \multirow[t]{2}{*}{$\operatorname{LSD}(0.05)^{\ddagger}$} & 365 & 1.4 & 1 & 2 \\
\hline & \multicolumn{4}{|c|}{2004} \\
\hline Nuplains & 4308 & 77.9 & 157 & 71 \\
\hline Nekota & 4021 & 75.9 & 152 & 74 \\
\hline Anton & 4374 & 76.4 & 156 & 71 \\
\hline Average all entries ${ }^{\dagger}$ & 4477 & 75.9 & 155 & 77 \\
\hline $\operatorname{LSD}(0.05)^{\ddagger}$ & 130 & 0.8 & 1 & 3 \\
\hline
\end{tabular}

This value is the average of all the values for the traits for the entries that were in the trial and includes values for many experimental lines not shown in the table.

FThe LSD (least significant difference $p<0.05$ ) was calculated from the analysis of variance using all of the values of the entries that were in the trial including many experimental lines not shown in the table.

the Southeast, South Central, West Central, and West Rainfed reporting districts. In these same districts, Anton had a significantly lower grain yield than NE01643. NE01643 ranked either first, second, or third in these districts over the 2005-2007 harvest years (UNL, 2009). In the West Irrigated trials, the average grain yield of Anton did not differ significantly from that of any of these cultivars (Table 2). In the irrigated sites, the grain yield of Anton was equal to, or significantly greater than, all trial entries, with the exception of the three highest entries over this 3-yr time period, 'Bond CL' (PI 639924), 'NuFrontier' (PVP 200100199), and 'TAM 111' (PI 631352). The average grain volume weights and grain protein contents of Anton did not differ significantly from those of any of these cultivars in any of the districts over the 3-yr test period (Table 2).

\section{End-Use Quality and Tolerance to Preharvest Sprouting}

Anton carries the high-molecular-weight glutenin subunits $2^{*}, 7+8$, and $5+10$, which are encoded by the respective alleles Glu-A1b, Glu-B1b, and Glu-D1d. Anton displayed significantly harder kernels, longer Mixograph and bake mix times, and greater Mixograph tolerance scores than the three check cultivars from the 2003 and 2004 NRPN (Table 3). The levels of flour PPO in Anton were significantly lower than those of the control cultivars and thus contributed to significantly lower changes in noodle brightness values $\left(\mathrm{L}^{*}\right)$ over a 24-h test period. Flour-PPO levels of Anton also were significantly lower than all other entries in the 2003 and 2004 NRPN (not shown). Few additional significant differences in the quality of Anton, relative to the controls, were noted. Grain-PPO activity of Anton, which was evaluated in samples collected from nine locations of the University 
Table 2. Grain yield, grain volume weight, grain protein content, plant height, and lodging of Anton, relative to check varieties and by district, in Nebraska for rainfed (37 environments) and irrigated trials (11 environments) grown from 2005 to 2007.

\begin{tabular}{|c|c|c|c|c|c|c|c|c|c|c|}
\hline Cultivar & $\begin{array}{l}\text { Grain } \\
\text { yield }\end{array}$ & $\begin{array}{c}\text { Grain } \\
\text { volume } \\
\text { weight }\end{array}$ & $\begin{array}{l}\text { Grain } \\
\text { protein } \\
\text { content }\end{array}$ & $\begin{array}{l}\text { Plant } \\
\text { height }\end{array}$ & Lodging & $\begin{array}{l}\text { Grain } \\
\text { yield }\end{array}$ & $\begin{array}{c}\text { Grain } \\
\text { volume } \\
\text { weight }\end{array}$ & $\begin{array}{c}\text { Grain } \\
\text { protein } \\
\text { content }\end{array}$ & $\begin{array}{l}\text { Plant } \\
\text { height }\end{array}$ & Lodging \\
\hline & $\mathrm{kg} \mathrm{ha}^{-1}$ & $\mathrm{~kg} \mathrm{hL}^{-1}$ & $\mathrm{~g} \mathrm{~kg}^{-1}$ & $\mathrm{~cm}$ & $\%$ & $\mathrm{~kg} \mathrm{ha}^{-1}$ & $\mathrm{~kg} \mathrm{hL}^{-1}$ & $\mathrm{~g} \mathrm{~kg}^{-1}$ & $\mathrm{~cm}$ & $\%$ \\
\hline & \multicolumn{5}{|c|}{ Southeast } & \multicolumn{5}{|c|}{ South Central } \\
\hline NE01643 (Overland) & 5165 & 78.8 & 116 & 91 & 1.6 & 4055 & 70.3 & 128 & 92 & 11.3 \\
\hline Millennium & 4667 & 77.3 & 117 & 94 & 2.6 & 3833 & 70.7 & 128 & 94 & 12 \\
\hline Wesley & 4391 & 74.4 & 117 & 84 & 1 & 3679 & 66.3 & 125 & 84 & 11 \\
\hline Mace & 4257 & 75.1 & 118 & 83 & 4.1 & 3450 & 69.9 & 132 & 85 & 16.3 \\
\hline Jagalene & 4223 & 76.5 & 116 & 87 & 7.1 & 3497 & 69.0 & 125 & 85 & 19.3 \\
\hline Antelope & 4143 & 74.7 & 118 & 89 & 5.4 & 3477 & 68.9 & 134 & 86 & 22.7 \\
\hline Anton & 4022 & 76.6 & 121 & 86 & 1.6 & 3477 & 69.3 & 134 & 82 & 5.3 \\
\hline Average all entries ${ }^{\dagger}$ & 4385 & 76.0 & 117 & 90 & 8.4 & 3490 & 69.5 & 129 & 88 & 21.3 \\
\hline \multirow[t]{2}{*}{$\operatorname{LSD}(0.05)^{\ddagger}$} & 753 & 4.0 & 4 & 7 & 17.9 & 612 & 3.5 & 5 & 7 & 22.1 \\
\hline & \multicolumn{5}{|c|}{ West Central } & \multicolumn{5}{|c|}{ West Rainfed } \\
\hline NE01643 (Overland) & 4075 & 76.1 & 122 & 86 & 7.6 & 3181 & 77.0 & 105 & - & 75 \\
\hline Millennium & 3921 & 76.4 & 125 & 88 & 6.3 & 2952 & 76.5 & 110 & - & 75 \\
\hline Wesley & 3652 & 73.7 & 123 & 75 & 8.6 & 2831 & 76.0 & 110 & - & 70 \\
\hline Mace & 3632 & 74.0 & 125 & 77 & 8.8 & 2818 & 74.7 & 109 & - & 69 \\
\hline Jagalene & 3436 & 75.6 & 125 & 80 & 8.8 & 3006 & 77.4 & 105 & - & 69 \\
\hline Antelope & 3416 & 74.7 & 125 & 80 & 8.3 & 2831 & 76.0 & 110 & - & 70 \\
\hline Anton & 3241 & 73.8 & 127 & 77 & 3.9 & 2757 & 76.5 & 110 & - & 70 \\
\hline Average all entries ${ }^{\dagger}$ & 3618 & 74.8 & 124 & 84 & 10.7 & 2946 & 76.2 & 107 & - & 73 \\
\hline \multirow[t]{2}{*}{$\operatorname{LSD}(0.05)^{\ddagger}$} & 410 & 1.7 & 5 & 4 & 9.7 & 229 & 1.7 & 6 & - & 5 \\
\hline & \multicolumn{5}{|c|}{ West Irrigated } & & & & & \\
\hline NE01643 (Overland) & 5736 & 75.5 & 113 & 83 & 10.8 & & & & & \\
\hline Millennium & 5582 & 76.2 & 113 & 86 & 11.3 & & & & & \\
\hline Wesley & 5831 & 74.7 & 119 & 73 & 3.9 & & & & & \\
\hline Mace & 5777 & 73.8 & 115 & 76 & 4.3 & & & & & \\
\hline Jagalene & 5763 & 75.7 & 116 & 76 & 11.4 & & & & & \\
\hline Antelope & 5683 & 76.2 & 115 & 78 & 6.3 & & & & & \\
\hline Anton & 5662 & 76.1 & 114 & 76 & 0 & & & & & \\
\hline Average all entries ${ }^{\dagger}$ & 5804 & 75.7 & 114 & 78 & 8.1 & & & & & \\
\hline $\operatorname{LSD}(0.05)^{\ddagger}$ & 343 & 1.4 & 6 & 3 & 9.9 & & & & & \\
\hline
\end{tabular}

of Nebraska wheat variety trial in 2005, did not differ significantly from that of the low-PPO cultivar Platte and was significantly lower than that of all other white wheats in the trial (Table 4). Anton's low PPO was, therefore, consistently observed across years and environments and in both grain and flour samples. Anton was found to be moderately susceptible to preharvest sprouting (Table 5). Its mean $\Delta$ area value was lower than that of the susceptible hard white winter wheats Antelope and Platte, equal to that of Arrowsmith, but significantly higher than that of the tolerant hard white wheat cultivars Trego and Nuplains. Anton's mean $\Delta$ area value was significantly higher than that of all hard red wheats tested with the exception of Pronghorn. Pronghorn, known from previous observations to be a susceptible hard red winter wheat, displayed a significantly higher mean $\Delta$ area. Cultivation of Anton, therefore, is not recommended for areas that routinely experience conditions amenable to preharvest sprouting.

\section{Availability}

The Nebraska Foundation Seed Division of the University of Nebraska-Lincoln, Lincoln, NE 68583 had foundation seed available to qualified certified seed enterprises in 2008 . The USDA will not have seed for distribution. The seed classes will be Breeder, Foundation, Registered, and Certified. Anton (PVP 200800301) was granted plant variety protection under P.L. 10577 with the certification option. Small quantities of seed for research purposes may be obtained 
Table 3. End-use quality attributes of Anton compared with check cultivars from the 2003 and 2004 Northern Regional Performance Nursery.

\begin{tabular}{|c|c|c|c|c|c|c|c|c|c|}
\hline Cultivar & $\begin{array}{l}\text { Kernel } \\
\text { weight }\end{array}$ & $\begin{array}{c}\text { Grain } \\
\text { hardness } \\
\text { score }\end{array}$ & $\begin{array}{c}\text { Grain } \\
\text { protein } \\
\text { concentration }\end{array}$ & $\begin{array}{l}\text { Flour } \\
\text { milling } \\
\text { yield }\end{array}$ & $\begin{array}{c}\text { Flour } \\
\text { ash } \\
\text { content }\end{array}$ & $\begin{array}{l}\text { Flour } \\
\text { PPO }^{\dagger}\end{array}$ & $\Delta \mathrm{L}^{\ddagger}$ & \multirow[t]{2}{*}{$\Delta \mathrm{a}^{\ddagger}$} & \multirow[t]{2}{*}{$\Delta \mathrm{b}^{\ddagger}$} \\
\hline & $\mathrm{mg}$ & & \multicolumn{3}{|c|}{$\mathrm{g} \mathrm{kg}^{-1}$} & $\mathrm{AU}_{475}$ & & & \\
\hline Nekota & 32.3 & 64.8 & 131 & 65.9 & 3.1 & 0.51 & -10.16 & 1.03 & 1.34 \\
\hline Nuplains & 28.5 & 73.4 & 135 & 66.7 & 3.3 & 0.47 & -10.72 & 1.10 & 1.92 \\
\hline Darrell & 30.8 & 74.5 & 134 & 67.2 & 3.5 & 0.42 & -10.71 & 1.06 & 2.75 \\
\hline Anton & 29.4 & 80.3 & 136 & 65.0 & 4.0 & 0.16 & -9.03 & 0.84 & 3.64 \\
\hline LSD (0.05) & 2.0 & 6.1 & ns & ns & ns & 0.091 & -0.58 & ns & 0.97 \\
\hline \multirow[t]{2}{*}{ Cultivar } & $\begin{array}{c}\text { Flour } \\
\text { protein } \\
\text { concentration }\end{array}$ & $\begin{array}{c}\text { Mixograph } \\
\text { water } \\
\text { absorption }\end{array}$ & $\begin{array}{c}\text { Mixograph } \\
\text { time }\end{array}$ & $\begin{array}{c}\text { Mixograph } \\
\text { tolerance }\end{array}$ & $\begin{array}{c}\text { Bake } \\
\text { water } \\
\text { absorption }\end{array}$ & $\begin{array}{l}\text { Bake } \\
\text { mix } \\
\text { time }\end{array}$ & $\begin{array}{l}\text { Loaf } \\
\text { crumb } \\
\text { score }\end{array}$ & & \\
\hline & \multicolumn{2}{|c|}{$\mathrm{g} \mathrm{kg}^{-1}$} & $\min$ & $0-6^{\S}$ & $\mathrm{g} \mathrm{kg}^{-1}$ & $\min$ & $0-59$ & & \\
\hline Nekota & 111 & 631 & 3.3 & 3 & 631 & 4.4 & 3 & & \\
\hline Nuplains & 115 & 638 & 2.7 & 2 & 624 & 3.4 & 4 & & \\
\hline Darrell & 115 & 639 & 3.8 & 4 & 632 & 5.3 & 3 & & \\
\hline Anton & 116 & 642 & 4.4 & 5 & 649 & 6.5 & 3 & & \\
\hline LSD (0.05) & ns & ns & 0.6 & 1.0 & ns & 1.0 & ns & & \\
\hline
\end{tabular}

†PPO, polyphenol oxidase.

${ }^{\ddagger}$ Noodlemaking property: change in alkaline noodle color over $24 \mathrm{~h}$ by Minolta colorimeter.

$\S 0=$ weak; 6 = strong.

"0 = unacceptable, 5 = excellent.

Table 4. Mean grain polyphenol oxidase of Anton relative to additional hard white winter wheats from nine locations of the 2005 University of Nebraska wheat variety trial.

\begin{tabular}{lc}
\hline Line or cultivar & ${\text { Grain } \text { PPO }^{+}}^{+}$ \\
\hline Platte & $\mathrm{AU}_{475}$ \\
Anton & 0.34 \\
Antelope & 0.35 \\
NW97S139-1 & 0.73 \\
Trego & 0.77 \\
Nuplains & 0.79 \\
NP-02 & 0.80 \\
NW99L7068 & 0.82 \\
LSD (0.05) & 0.90 \\
\hline
\end{tabular}

${ }^{\dagger} \mathrm{PPO}$, polyphenol oxidase activity.

from Dr. Robert Graybosch, USDA-ARS, Department of Agronomy and Horticulture, University of Nebraska-Lincoln, 68583 for at least $5 \mathrm{yr}$ from the date of this release. A seed sample has been deposited in USDA-ARS National Plant Germplasm System and in the USDA-ARS National Small Grains Collection, Aberdeen ID, where Anton is catalogued as PI 651043.

\section{Acknowledgments}

Financial support from the Nebraska Wheat Board is gratefully acknowledged. The authors thank Lori Divis, Vern Hansen, Greg Dorn, Mitch Montgomery, and Chris Hoagland for technical assistance, and Brigid Amos for suggesting the use of the LI-COR Area Meter in the assessment of sprouting tolerance.
Table 5. Mean preharvest sprouting tolerance of Anton relative to hard red and hard white winter wheats grown at Mead, NE from 2007 to 2009.

\begin{tabular}{llcc}
\hline Entry & $\begin{array}{c}\text { Market } \\
\text { class }^{\dagger}\end{array}$ & $\Delta$ area & $\begin{array}{c}\text { Standard } \\
\text { error }\end{array}$ \\
\hline Alliance & HRWW & 62.3 & 7.0 \\
Antelope & HWWW & 101.8 & 4.5 \\
Anton & HWWW & 85.7 & 6.1 \\
Arapahoe & HRWW & 59.9 & 6.4 \\
Arrowsmith & HWWW & 85.0 & 5.0 \\
Jagalene & HRWW & 43.7 & 7.1 \\
Camelot & HRWW & 40.3 & 6.7 \\
NE02584 & HRWW & 52.4 & 7.7 \\
NI01481 & HRWW & 67.2 & 6.7 \\
NI04420 & HRWW & 48.2 & 7.2 \\
Nuplains & HWWW & 46.9 & 5.2 \\
Overland & HRWW & 62.0 & 5.8 \\
Platte & HWWW & 109.6 & 6.6 \\
Pronghorn & HRWW & 98.1 & 7.6 \\
Trego & HWWW & 69.0 & 7.3 \\
Wesley & HRWW & 39.1 & 6.6 \\
\hline
\end{tabular}

${ }^{\dagger}$ HRWW, hard red winter wheat; HWWW, hard white winter wheat.

\section{References}

Anderson, J.V., and C.F. Morris. 2001. An improved whole-seed assay for screening wheat germplasm for polyphenol oxidase activity. Crop Sci. 41:1697-1705.

Blechl, A.E., and O.D. Anderson. 1996. Expression of a novel highmolecular weight glutenin subunit gene in transgenic wheat. Nat. Biotechnol. 14:875-879.

Payne, P.I., and G.J. Lawrence. 1983. Catalogue of alleles for the complex gene loci, Glu-A1, Glu-B1, and Glu-D1 which code for highmolecular-weight subunits of glutenin in hexaploid wheat. Cereal Res. Commun. 11:29-35. 
Peterson, C.J. 1992. Similarities among test sites based on line performance in the hard red winter wheat region. Crop Sci. 32:907-912.

Peterson, C.J., R.E. Allan, G.L. Rubenthaler, K.J. Morrison, and O.A. Vogel. 1987. Registration of Dusty winter wheat. Crop Sci. 27:1315.

Peterson, C.J., R.A. Graybosch, P.S. Baenziger, D.R. Shelton, W.D. Worrall, L.A. Nelson, D.V. McVey, and J.H. Hatchett. 1993. Registration of N86L177 wheat germplasm. Crop Sci. 33:350.

University of Nebraska-Lincoln (UNL). 2009. CropWatch. Variety testing. Available at http://cropwatch.unl.edu/web/varietytest/ wheatarchive (verified 29 July 2010).
USDA-ARS. 2009a. Hard Winter Wheat Quality Laboratory. Available at http://www.ars.usda.gov/Main/docs.htm?docid=14298 (verified 29 July 2010).

USDA-ARS. 2009b. Hard winter wheat regional nurseries. Available at http://www.ars.usda.gov/Research/docs.htm?docid=11932 (verified 29 July 2010). 